\title{
NETNOGRAPHY : GOJEK MARKETING STRATEGY ANALYSIS THROUGH YOUTUBE SOCIAL MEDIA
}

\author{
Siti Fatimah \\ Faculty of Business, Law and Social Sciences, Universitas Muhammadiyah Sidoarjo \\ Email: sitifatimah@umsida.ac.id \\ Mirza Chusnainy \\ Faculty of Business, Law and Social Sciences, Universitas Muhammadiyah Sidoarjo \\ Email: mirzschsn@gmail.com
}

Fifi Khumairo

Faculty of Business, Law and Social Sciences, Universitas Muhammadiyah Sidoarjo Email: fifikhumairo@gmail.com

Shinta Didin Hari Mariana

Faculty of Business, Law and Social Sciences, Universitas Muhammadiyah Sidoarjo Email:didin182sukses@gmail.com

\section{Sigit Hermawan}

Faculty of Business, Law and Social Sciences, Universitas Muhammadiyah Sidoarjo Email: sigithermawan@umsida.ac.id

\begin{abstract}
PT Aplikasi Karya Anak Bangsa or Gojek is an online transportation service company that was founded in 2010. The research objective is to analyze and describe Gojek's marketing strategy through YouTube social media. This research uses a qualitative approach, with analysis using netnographic studies. The research subjects are 20 netizens who commented on Gojek's Indonesian Youtube account related to the video marketing advertising Gojek. The results showed that Gojek's marketing strategy made use of the internet as a means to promote the services offered. The promotion process is very intensively carried out by the Gojek Company, one of which is through social media. With the sophistication of advertising done through media social, users will automatically be treated to various promotions from the CompanyGojek when opening its social media pages. This strategy is very appropriate because almost the entire process of purchasing a Gojek service is done ina smartphone application, this means that the potential consumers targeted are in accordance with the ad audience that is installed. The conclusion in this study is the implementation of marketing $7 \mathrm{P}$ on online Gojek services which include: product, price, place, people, process, and physical evidence has been implemented well.
\end{abstract}

Keywords: Marketing Strategy; YouTube Social Media; 7P Marketing.

\begin{abstract}
Abstrak
PT Aplikasi Karya Anak Bangsa atau Gojek merupakan perusahaan jasa transportasi online yang berdiri sejak tahun 2010. Tujuan dari penelitian ini adalah untuk menganalisis dan mendeskripsikan strategi pemasaran Gojek melalui media sosial YouTube. Penelitian ini menggunakan pendekatan kualitatif, dengan analisis menggunakan studi netnografi. Subjek penelitian ini adalah 20 orang netizen yang mengomentari akun Youtube Indonesia Gojek terkait iklan pemasaran video Gojek. Hasil penelitian menunjukkan bahwa strategi pemasaran Gojek memanfaatkan internet sebagai sarana mempromosikan layanan yang
\end{abstract}


ditawarkan. Proses promosi sangat gencar dilakukan oleh Perusahaan Gojek, salah satunya melalui media sosial. Dengan kecanggihan periklanan yang dilakukan melalui media sosial, otomatis pengguna akan disuguhi berbagai promosi dari Perusahaan Gojek saat membuka halaman media sosialnya. Strategi ini sangat tepat karena hampir seluruh proses pembelian layanan Gojek dilakukan dalam aplikasi smartphone, artinya calon konsumen yang diincar sesuai dengan audiens iklan yang dipasang. Kesimpulan dalam penelitian ini adalah implementasi pemasaran 7P pada layanan Gojek online yang meliputi: produk, harga, tempat, orang, proses, dan bukti fisik telah terlaksana dengan baik.

\section{Kata kunci: Strategi Pemasaran; Media Sosial YouTube; Pemasaran 7P.}

How to Cite: Fatimah, S., Chusnainu, M., Khumairo, F., Mariana S. D. H., \& Hermawan, S. (2021). Netnography : Gojek Marketing Strategy Analysis Through YouTube Social Media. Media Ekonomi dan Manajemen, 36(1), 39-61. doi: http://dx.doi.org/ 10.24856/mem.v36i1.1601.

\section{INTRODUCTION}

Indonesian Internet Service Providers Association (APJII) released data that until 2017 internet users in Indonesia reached 143 million people, which is more than $50 \%$ of Indonesia's population of 262 million people. Utilization of the internet has now evolved into a means of global information and communication in the business world. One of its uses is as an advertising medium (advertising tool) that functions to promote products or advertise via the internet (Kotler \& Armstrong, 2004). Data released by the Indonesian Internet Service Providers Association (APJII) states that around $87 \%$ of people in Indonesia use internet services to access social media (Firmansyah, 2018).

One form of social media that always offers the latest products is YouTube. Through YouTube, everyone will get a variety of information, entertainment, and of course the latest product advertising information. The latest advertisement product offerings through the YouTube media will provide convenience for consumers in watching broadcast advertisements (Ramadhayanti, 2019).

Transportation is a very important means in supporting human activities or mobility every day so it must be prepared properly and safely. As one of the transportation facilities that are widely used by Indonesian people, Indonesian taxi service online offers a variety of alternative service provision that has been available in various big cities in particular to assist the community in carrying out their daily activities, such as work activities, lectures, traveling, research, trade and travel others (Farida et. al, 2016).

Promotion is one way to introduce business products. With promotion, the product will be far more easily known to the public and easily reached by the target consumer (Anindhita, Arisanty, \& Rahmawati, 2016). Gojek continues to innovate to make promotions in order to gain consumer confidence. One of the promotions issued by this company is "Gojek Your Version". Through this promotion, consumers are free to determine the order of service options in the Gojek App application, ranging from the most frequent to the least used by consumers. Each of these versions was promoted in the form of advertisements via YouTube (Soelistyowati, 2018). In addition there are also advertisements Introducing Jo \& Jek that take the topic of driving guides that are demonstrated by Jo (customer) and Jek (partners). Creativity in packaging the ad impressions Introducing humorous and humorous Jo \& Jek stole the hearts of netizens. Even this caused a relatively short period of time, the ad that lasted for four minutes and six seconds was successfully watched more than 5.5 million times, liked by 18 thousand 
viewers, and received approximately 1.5 thousand comments as of May 6, 2019 (Swastika , 2019).

The company can see testimonials or comments, criticisms, and suggestions made by citizens from Youtube as their "correction material" in improving the quality and services provided by the company to its consumers. Management makes the most of its use from introducing services to a wide audience, prices, and how these services serve their audience. In addition, the real form of marketing elements is very visible when viewed from the activity, information content, and the number of users who join in each social media account (Soelistyowati, 2018).

This business and technology development requires companies to formulate marketing strategies to win market competition. The purpose of this marketing strategy is to find and retain the intended consumer by providing and communicating product values to customers (Kotler \& Armstrong, 2008). The most widely used marketing strategy is to implement advertising. Gojek is a pioneer of professional motorcycle taxi service providers who strive to offer speed, safety and comfort to their customers.

The reason for using the Gojek motorbike shuttle service is because the price is relatively cheap, ranging from $\mathrm{Rp}$ 10,000 to $\mathrm{Rp} 15,000$, which can reach the public. In addition, the existence of this Gojek rider is everywhere, the driver is friendly to his fellow riders but also friendly to his customers, the service is so fast and the cleverness in driving his vehicle is not in doubt, besides that many provide services that can be found with just one touch on media smartphone(Farida et. Al., 2016).

By using the Gojek application, consumers can order Gojek Drivers to access all of these services. By entering the address to find out the cost of using the service. Use the "Use My Location" service to direct the driver to where the
User is located. After confirming the order, technology location-based will find the driver whose position is closest to the consumer. After a driver is assigned, the consumer can see a photo of the driver, send a short message, and also call him (Clearesta, Angelina, \& Wiradharma, 2015).

Gojek marketing strategy via YouTube is a strategy that is also carried out by many companies especially on YouTube there are subscriber and comment. Through subscriber a high and good comments can certainly win the hearts of consumers. If consumers watch YouTube and are confident with the product, then the consumer will usually go to the next stage, namely in the decision to buy the product (Ramadhayanti, 2019).

\section{Research Objectives}

The research objective is to analyze and describe Gojek's marketing strategy through YouTube social media.

\section{LITERATURE REVIEW Marketing}

According to Stanton (2001) marketing is an overall system of business activities aimed at planning, pricing, promoting and distributing goods or services that satisfy the needs of both existing and potential buyers. According to Sudaryono (2016) marketing is a management process that seeks to maximize profits (returns) for shareholders by establishing relationships with key customers (valued customers) and creating competitive advantages. Marketing is a business process that seeks to align the organization's human, financial and physical resources with the needs and desires of customers in the context of competitive strategies.

\section{Marketing Mix}

According to Kotler \& Armstrong (2012) the marketing mix is a set of marketing tools used by a company to continuously achieve its marketing 
objectives in the target market. In the marketing mix there are a set of tools that are known in terms of 4P, namely product, price, place or distribution channel, and promotion, while service marketing has several additional marketing tools such as people), physical evidence (physical facilities), and process (process), so that it is known as 7P, it can be concluded that the marketing mix is product, price, place, promotion, people, physical evidence, and process. The understanding of 7P according to Kotler \& Armstrong (2012) is as follows: (1) Products (products), (2) Price (price), (3) Distribution (place), (4) Promotion (promotion), (5) Means physical (physical evidence), (6) people (people), and (7) the process (process).

\section{Marketing Strategy}

According to Kotler \& Armstrong (2012) marketing strategy is a mindset that will be used to achieve marketing objectives in a company, it can be about specific strategies for the target market, positioning, marketing mix, and the amount of a marketing expenditure. Tambajong (2013) states that a marketing strategy is a fundamental tool that is planned to achieve the company by developing competitive advantage through the markets entered and marketing programs that are used to serve the target market.

\section{Elements of Marketing Strategy}

One element in the marketing strategy is the marketing mix which is a strategy run by the company which is related to determining how the company presents its product offerings in certain market segments, which are its target market. There are four elements of the marketing mix which are marketing strategies. The elements used as a marketing mix according to Assauri, (2013) are as follows:

First, product strategy. The product strategy in this case is to establish ways and to provide the right products for the target market, so that it can satisfy its customers and at the same time increase company profits in the long run, through increasing sales and increasing market share. The product strategy that can be carried out includes decisions on product mix, brand, product packaging, product quality, and services provided.

Second, pricing strategy. Price is the only element of the marketing mix that generates sales revenue, while the other elements are just ordinary elements. The role of prices is very important especially to maintain and improve the company's position in the market, which is reflected in the company's market share, in addition to increasing sales and company profits. In other words, pricing affects the company's competitive ability and the company's ability to influence consumers.

Thirst, distribution strategy. Distribution is the activity of delivering the product to the hands of the user or the consumer at the right time. Distribution policy is one of the integrated marketing policies that includes the determination of marketing channels (marketing channels) and physical distribution.

Fourth, Promotion Strategy. Companies must try to influence consumers, to create demand for the product, then maintained and developed through promotional activities which are one of the references / marketing mix. Promotions must be in line with the overall marketing plan, and planned to be well directed and controlled. According to Tjiptono (2002) promotion is a form of marketing communication meaning marketing activities that seek to disseminate information, influence / persuade and or remind target markets for companies and their products to be willing to accept, buy, and be loyal to the products offered by the companies concerned. According to Sistaningrum (2002) promotion is an effort or activity of a company in influencing actual and potential consumers so that they are willing to make a purchase of products offered now or in the future. According to Kotler (2000) promotion is a part and process of marketing strategy as a way to communicate with the market using 
the promotional mix composition. According to Lupiyoadi \& Hamdani (2006) promotion is one of the variables in the marketing mix that is very important to be implemented by companies in marketing service products.

\section{Social media}

According to Carr \& Hayes (2015) social media is internet-based media that allows users the opportunity to interact and present themselves, both instantaneously and delayed, with a wide audience or not that encourages the value of user-generated content and perceptions of interaction with others.

\section{Digital Marketing}

According to Sanjaya \& Tarigan (2009) digital marketing is marketing activities including branding that uses various web-based media such as blogs, websites, e-mails, adwords, or social networking. According to Turban (2004) digital marketing uses the internet and information technology to expand and enhance traditional marketing functions.

\section{Gojek}

Gojek (PT Aplikasi Karya Anak Bangsa) is an original technology company Indonesia that serves transportation through services motorcycle taxi. This company was founded in 2010 at Jakarta by Nadiem Makarim. Currently, Gojek has been available in 50 cities in Indonesia. As of June 2016, the Gojek app has been downloaded nearly 10 million times on Google Play on the operating Android system and has been available at App Store. Gojek also has a digital payment service called Gopay (Gojek, 2019).

\section{Youtube}

Youtube is a website that facilitates users to share videos they have, or to the extent that they enjoy various video clips uploaded by various parties. There are various kinds of videos that can be uploaded to this site (Hermawan, 2019).

\section{RESEARCH METHOD Data Type and Source}

This research uses a qualitative approach, with a knife analysis using netnographic studies. Qualitative research is research that explains phenomena in the form of words and does not use numbers and does not use various measurements. Qualitative research can be used in a variety of approaches, including: ethnography, naturalistic studies, case studies, field studies, technical work, and direct observation. This approach uses a variety of methodologies that are characteristic of qualitative research (Hermawan \& Amirullah, 2016).

This method was chosen because of this research, using the internet as a field of research. According to Kozinets (2010) netnography is a research method specifically designed to study culture and online communities. Netnographic researchers conduct ethnographic research on online culture. Virtual community researchers use computer media that has internet facilities and conduct data collection techniques in cyberspace, retrieve / download information from websites related to research, conduct interviews via chat / email (electronic interviews), observe virtual rooms (websites) as a gathering place members of the virtual community.

The writing of this article also uses the literature study method with a qualitative approach. The literature study method makes it possible to test a hypothesis and develop new theories by summarizing, analyzing, and synthesizing relevant literature groups (Denney \& Tewksbury, 2013).

\section{Research Focus}

Focus of this research is the analysis of Gojek's marketing strategy through social media YouTube. The focus of the study entitled Gojek marketing strategy analysis through social media YouTube is with the 7P dimension: (1) Products, (2) Price, (3) Place, (4) Promotion, (5) People, (6) Processes, and (7) Physical environment. 
Determination of Informant Techniques

Determination of research subjects in this study using purposive sampling techniques (Sugiyono: 2011). The research subjects in this study were 20 netizens who commented on Gojek's Indonesian Youtube account related to the video marketing advertising Gojek.

\section{Data Collection}

Primary data collection techniques were carried out by observation and documentation. Researchers visit the website and YouTube as a forum for interaction for members of the virtual community. Observations were made on laptops and smartphones connected to the internet. Researchers study the beliefs, values and customs and behavior of certain communities or groups online.

Besides that, researchers also collect secondary data. The data source used in this research is literature study by studying journals, websites, online articles and other media relating to the analysis of marketing strategies Gojek through social media YouTube.

\section{Data Analysis}

Techniques of analyzing data qualitatively according to Miles \& Huberman (in Sugiyono, 2011), namely: Data collection. The netnographic procedure implements an ethnographic procedure that is observation-participation using internet media such as computers, smartphones, and social media. Data collection is done by observation, documentation, and literature study using the internet in the form of journals, online articles, Indonesian Gojek website, and YouTube Gojek Indonesia. All data collected from various sources is read, studied, and analyzed. Data reduction. Data reduction is defined as summarizing and retrieving essential and important data. In reducing data, each researcher will be guided by the objectives to be achieved. Data Presentation. In qualitative research, the presentation of data can be done in the form of brief descriptions and tables. Narrative text is the data presentation most often used in qualitative research. Conclusion. The author gives several small conclusions before writing the final conclusions clearly.

\section{RESULTS AND DISCUSSION Gojek Application Innovation Features and Services}

Through the Gojek application, users can access various services. The features and services offered through the Gojek application are as follows: Go-ride. Allows users to go anywhere almost easily, quickly and simply. Users can order a GoRide with a distance of $30 \mathrm{~km}$. Also great is that users can order Go-Ride services more than once at the same time. What a user must do before ordering a Go-Ride service is to make sure they are ready for pickup. This makes it easier for drivers who will go directly to the coordinates according to the order made. Ease of the latest version of the Go-Ride application, users can chat directly with the Go-Ride driver through the chat feature in application.

Go-pay. An electronic money that users can use to pay for all financial transactions through the Gojek application. Payments via Go-Pay can be done when the user places an order for Go-Ride, GoCar, Go-Box, Go-Credit and so on. In addition, Go-Pay can also be used to pay for financial transactions online. Then, it can also pay for transactions in stores, outlets and even restaurants that have been registered as Go-Pay business partners by scanning a QR code. How to use Go-Pay for all Gojek services is very easy, that is, after the user completes an order, there will be an option for payment methods, one of which is Go-Pay. Then the way to top up your GO-PAY balance is also fairly simple, i.e. can use one of the following channels: (a) BCA OneClick, (b) Bank transfer via ATM, SMS Banking or Mobile Banking, (c) Transfer via driver (Go -Ride, Go-Car, Go-Food and Go-Shop), (d) Transfers through Alfa Group such as Alfamart, Alfamidi and Lawson, and (e) 
Pegadaian. While the Go-Pay balance limit is different depending on whether it has been upgraded or not. If not, then the maximum limit is Rp. 2,000,000. But when it has been upgraded it can save a balance of up to Rp 10 million.

Go Send. Users can use this service if the user wants to send goods / packages in the same area. The maximum distance of the package pickup point is $100 \mathrm{~km}$ from the user's location point. Users can order Go-Send more than once. However, before the user orders the Go-Send service, it must ensure that the goods / packages that the user will send have the following terms and conditions: (a) Dimensions $70 \mathrm{x}$ $50 \times 50 \mathrm{~cm}$, (b) Not animals, (c) Not broken goods split, (d) Not prohibited goods such as drugs, (e) Non-perishable goods, (f) Maximum weight of $20 \mathrm{~kg}$, and (g) Not serving parcels of shipping to and from prison. To check the progress of packages that users have sent, you can immediately see the current position of the driver in the "Order" menu.

Go-car. Users can use this service to meet the transportation needs of users and families that are safer, simpler, and easier. The maximum distance allowed when ordering a Go-Car is $100 \mathrm{~km}$. By ordering a Go-Car, users are assured of getting a car service with a maximum of 4 people ready to take the user to their destination. In a few moments, when a user orders a GoCar, there is a possibility that the one who comes to pick up is a Blue Bird taxi and this isn't a problem. Before ordering this service make sure the position of the user and family is at the pick-up point to make it easier for drivers.

Go-food. For users who are hungry but lazy to go out can use the Go-Food service to order food within a maximum radius of $25 \mathrm{~km}$. Users can order food from more than 100,000 restaurants and outlets that have collaborated with Gojek. Interestingly, users can order food for friends from different areas by changing the user's location to the user's friend / family location. In addition, users can also order favorite menus again without the hassle of starting from scratch using the "Reorder" and "Favorites" features.

Go box. Users can use this feature for the purpose of sending goods in large quantities and sizes. There are many choices of vehicles that can be tailored to the needs of user packages. The maximum distance of the point of taking the package is $100 \mathrm{~km}$ from the distance the location of the user ordered Before the user makes an order, it must ensure that the package the user is sending matches the following criteria: (a) For Pick-up cars The maximum volume body is $200 \times 130 \times 120$ $\mathrm{cm}$ and the maximum weight is $1,000 \mathrm{~kg}$, (b) Pick-up cars The maximum volume box is $200 \times 130 \times 130 \mathrm{~cm}$ and the maximum weight is $1,000 \mathrm{~kg}$, (c) The Duct Truck The maximum volume is $300 \times 160$ $\mathrm{x} 130 \mathrm{~cm}$ and the maximum weight is $1,000 \mathrm{~kg}$, and (d) Then the Duct Truck The maximum volume box is $300 \times 160 \times 160$ $\mathrm{cm}$ and the maximum weight is $1,000 \mathrm{~kg}$. Additionally, it can continue to check the progress of the user's shipment by monitoring the location of the driver in the "Order" menu

Go-credit. Users can use this service to refill credit and data packages when suddenly run out. The trick is to enter the User's Go-Pay pin when making a topup transaction or data package. Don't forget to update the application so you can use this feature. The nominal price of pulses and data packages varies depending on the provider. Providers that have collaborated with Go-Pulsa are Telkomsel, XL Axiata, Indosat, Tri, Axis, and Smartfren.

Go-bills. This service offers users the convenience of paying various bills. GoBills can also be used to buy digital product vouchers directly from the application. Users can trade on Go-Bills by using the balance the User has on Go-Pay. Services that can be paid for using GoBills include PLN, BPJS Health, Google Play Voucher Codes, Multifinance Bills, Internet, Cable TV, PDAM, PGN, and GameVouchers. 
Go-shop. Is another alternative to Go-Food, i.e. if the food or product that the User ordered is not available in the GoFood service. The maximum delivery distance must be within a $25 \mathrm{~km}$ radius of the order point. You can be sure the GOJEK driver will buy the goods according to what the user wants. Go-Shop payment can use Go-Pay or cash.

Go-tix. With this service the user is facilitated because it allows the User to order various kinds of entertainment tickets such as concerts, theaters and other event tickets in the user's city. Additional fees charged for each ticket purchase is IDR 5,000. Those who have an event can also partner with GO-TIX by registering the event. There are 3 methods that users can use to pay for Go-Tix service transactions, namely Go-Pay (make sure enough balance before order), credit cards, and bank transfers. For every GO-TIX transaction details, you can always check "My Tickets".

Go-Deals. Is a service that will provide special offers / discounts in the form of vouchers from various categories. For example food and beverages, ecommerce and lifestyle. Users can buy it with the balance the User has on Go-Pay.

Go-Blue Bird. This is a service that will make it easier for users to order Blue Bird taxis. Users can travel easily and comfortably with taxis that have dozens of highly dedicated fleets.

Go-massage. With this service users can order experienced therapists directly to the user's home. This of course will be refreshing after a tired day of activities. With this service, users can order therapist services according to user needs such as full-body massage, pregnancy massage, and even sports massage.

Go clean. Is a service that users can order to clean the user's home or office. Cleaner comes from a professional person and also serves clothes ironing, washing clothes, washing dishes and so forth.

Go Auto. Users can take advantage to solve all problems related to automotive users. With a professional technician, GoAuto can fix almost all problems such as car servicing, tune ups, changing batteries or even just washing a user's car or motorcycle. Don't forget to order Go-Auto if the user experiences an emergency on the road anytime anywhere.

Go-Glam. Users can use this service to fulfill the desire to look beautiful users. With this service, users can order beauty experts directly to the user's home. Users can get complete treatments such as pedicure, manicure, cream bath, waxing, and facial and hair care. All users can get quickly and easily.

Go-Daily. This service offers to fulfill all daily needs of users such as mineral water and LPG gas. All are served by trained and professional employees. Go-fix. This service is specifically for helping all problems related to AC Users. Trained and professional workers are ready to repair, clean, and even move the user's air conditioner.

Go-Laundry. Users can order professional laundry services and free shipping. Laundry costs can be measured at the price per kilo. Meanwhile, this service is only available at Jabodetabek with business hours from 08.00 to 20.00 WIB (Markey, 2018).

\section{Segmenting, Targeting, and Positioning of Objects in the Indonesian Ojek Online Market}

According to Kotler \& Keller (2012) marketing strategies are based on segmentation, targeting, and positioning. Segmenting is the process of classifying heterogeneous whole markets into groups or segments that have similarities in terms of needs, desires, behavior, and responses to specific marketing programs (Kotler \& Keller, 2012). Targeting is the activity of determining the target market by selecting one or more segments to be served, evaluating the attractiveness of each segment, and choosing the right target segments (Kotler \& Keller, 2012). While positioning is a strategy that seeks to create 
a unique differentiation in the minds of target customers, so that a product image is formed that is superior to competitors (Kotler \& Keller, 2012). According to Lupiyoadi (2013) marketing and promotion strategies will be effective if the company understands its position in the market and meets customer needs. Market segmentation is dividing the market into groups of buyers which are distinguished according to their needs, characteristics, or behavior which may require different products (Kotler \& Keller, 2012). There are two segmentation approaches which are based on consumer characteristics and based on consumer responses (Tjiptono, 2014).

Segmentation based on consumer characteristics shows that demographically and socio-economically Gojek divides its market into several groups, namely the target group of employees, urban communities, and students. This grouping of consumers can be seen from how Gojek provides promos, in 2017. Gojek launches promos that are divided into groups of consumers, namely: (a) In the group of employees get a discount promo on working days around the office area. This promo is given randomly by analyzing the big data available to Gojek consumers, (b) In the general public group, Gojek provides promos on support services such as Go-Food, Go-Clean, to Go-Massage, and (c) In student groups, Gojek also provides promos based on where they study. Some promotions are very specific for trips to schools, campuses, and study centers. Consumers in this group get big discounts (Rizal, 2018).

In psychographic segmentation, Gojek targets middle and upper economic consumers both men and women in the SES A, B and C. categories. Gojek also divides consumers into middle and upper lifestyle groups, namely: (a) In society urban, Gojek only gives promos on discounts using Go-Pay, in contrast to Grab and Uber where urban promos use a discount code based on the place of order
(Rizal, 2018).

In segmentation based on consumer response, initially which is superior to competitors (Kotler \& Keller, 2012). According to Lupiyoadi (2013) marketing and promotion strategies will be effective if the company understands its position in the market and meets customer needs. Initially consumers thought of looking for transportation that provides a lot of convenience and benefits, so Gojek came to answer it all, not only providing shuttle services but also personal shopping and instant couriers (Mahayuni, Purnawan, \& Cahyani, 2014). Currently Gojek controls the personal shopping market with GoMed, Go-Shop, and Go-Food. Compared to Grab, all three of these Gojek services have high performance. After the acquisition with Uber, there was no influence on these three services, because the personal shopping service in Uber was not well known to consumers. Gojek's marketing strategy provides special services by offering promo codes for customers with heavy usage through points that can be exchanged for a variety of products and services (Rizal, 2018)

Market segmentation is dividing the market into groups of buyers which are distinguished according to their needs, characteristics, or behavior which may require different products (Kotler \& Keller, 2012). There are two segmentation approaches which are based on consumer characteristics and based on consumer responses (Tjiptono, 2014).

Sumangunsong, Aprianingsih, \& Magdalena (2017) explained that Gojek consumer loyalty fluctuates in accordance with the promos available at Grab, consumers usually switch for a moment when Gojek competitors are holding a discounted month. Furthermore Sumangunsong, Aprianingsih, \& Magdalena (2017) explained that Gojek customer loyalty is strongly influenced by price. As a technology company that is closely related to modern concepts, Gojek targets a very specific market, namely 
consumers who are in the productive age, know how to use smartphones and the internet, are in the middle and upper classes and have high mobility. The selection of target consumers based on the analysis of Wahid \& Puspita (2017) is very appropriate, because in this group of consumers the quantity is increasing and financially is at a peak condition which makes it easy to reach Gojek products.

Positioning includes the design and offering of a company's image so that the target market knows and attaches importance to the company's position in the eyes of competitors (Tjiptono, 2014). Gojek's slogan portrays Gojek's positioning in the market, in line with the slogan "An Ojek for Every Need", Gojek ensures that every consumer's needs can be met by using Gojek. This is supported by the launch of other services besides transportation services, such as delivering goods, buying food, buying medicine and other things related to couriers. But in its development, Gojek then provides other services that are in accordance with the daily needs of consumers such as cleaning the house, servise vehicles, to massage and others (Rizal, 2018).

\section{Implementation of 7P Gojek Marketing}

Implementation of 7P marketing on online Gojek services can be outlined as follows: Product. Gojek online provides a package of shuttle services both in the form of goods and people, where similar services in other businesses are still fragmented, such as only to deliver goods, but not for human transportation, or vice versa. Price. The price system offered is relatively cheaper, more open, and has the same standard based on the distance traveled, so customers can predict the possible costs they will incur. Place. Online ojek services are everywhere, so they are easy to get. Promotion. Gojek online uses promotional tools in the form of applications that can be downloaded on the commonly used personal communication tools (smartphones) and they also promote their services through other media tools. Browse. Gojek services have their own management, and the personnel involved are provided with basic training and a separate recruitment system. Process. To obtain Gojek services, customers can use the available online Gojek application, and specify the desired location (destination and pick-up place) so that it will facilitate the process of Gojek online services. Physical Evidence. The physical form of Gojek is green-white transportation and a helmet that reads "Gojek" (Farida et. al., 2016).

\section{Gojek's SWOT Analysis}

SWOT analysis is a way to analyze Gojek company's marketing strategy in its internal and external environment, which aims to detect and formulate policies that are strategic for the company. The implementation of the strategy for the field of marketing functions is started by considering the marketing mix, namely products, prices, distribution channels, and promotions. The mix of the marketing elements must be right and the plans of each element must also be right (Yuliantari, 2017).

Marketing mix is a variable that can be controlled by a company organization to make adjustments to the target market or affect the target market. Companies must develop strategies by synchronizing elements of the marketing mix to achieve the same goals. The marketing strategy starts with analyzing the overall situation of the company. Marketers must conduct a SWOT analysis, by assessing: (1)Strengths (S), (2)Weaknesses (W), (3) Opportunities (O), and (4) Company Threats (T) overall (Kotler \& Armstrong, 2008). Analysis of the data used to solve the problem are as follows:

Strengths (S), namely: (1) The pioneer of online motorcycle taxi service in a country with a memorable brand, (2) Besides sending customers to their destination, as a courier who delivers goods, also shopping and Go-Food services to buy goods / food particular, (3) 
The ease of ordering through online can be from a smartphone, (4) No need to worry about change or carrying cash with Go-Pay via ATM, mobile banking, from BCA, BRI Bank, and Bank Mandiri, (5) Drivers there are already more than 200 thousand drivers, (6) Drivers and partners get health and accident compensation, (7) Goals that give bonuses to drivers who are diligently looking for customers, (8) Gojek is not bound by work contracts as in the company in general, ( 9) The marketing fleet has been adequate, (10) The price of services is affordable and competitive, and (11) Remain concerned with the quality of service (Yuliantari, 2017).

Weakness (W), namely: (1) There is a "naughty" Gojek driver, (2) The application is often error (especially at rush hour), (3) Security of the Android operating system is a system that is very easily modified and has many security holes, and (4) Driver rejection of performance appraisal systems set by management that is not transparent (Yuliantari, 2017).

Opportunities (O), namely: (1) Has a potential market for growth, (2) Gojek has officially operated in 15 major cities in Indonesia and will continue to grow, (3) Partnering with around 200,000 experienced and trusted motorcycle taxi drivers in Indonesia, (4) The community's need for two-wheeled vehicle transportation services is increasingly high, (5) The patterns of behavior and tastes of consumers that are increasingly developing from conventional transportation services to online transportation services, (6) Online application technology that continues to grow, and (7) Jobs Gojek is considered to be more profitable than office work (Yuliantari, 2017).

Threats (T), namely: (1) More and more similar businesses are established, (2) Competitor prices are cheaper for some similar services, (3) Both Gojek and GrabBike both equip drivers with a green jacket and a logo on a helmet that is almost similar. This can confuse the customer, and
(4) Motorcycle taxi drivers often get threats or attacks from traditional motorcycle taxis (Yuliantari, 2017).

\section{Implementation of the Gojek SWOT Strategy}

After analyzing the external and internal environment, it can be formulated into a SWOT analysis that describes each of the strengths, weaknesses, opportunities and challenges of PT Gojek Indonesia. Based on internal strengths and weaknesses as well as external opportunities and threats, four sets of strategic alternatives that can be taken by PT Gojek Indonesia's managers in facing increasingly competitive competition are as follows:

Strengths-Opportunities strategy, namely:(1) Maintain and improve the quality of service in service to customers. PT Gojek Indonesia is the pioneer of online motorcycle taxi service in Indonesia with a brand that is easy to remember. It is known for its strong brand image and has good quality. Therefore, by maintaining and improving the quality of service, consumers will not hesitate to use the services of Gojek and (2) Market development in all circles. PT Gojek Indonesia is a pioneer in providing professional motorcycle taxi services. Trying to offer a factor of speed, safety, and comfort for its customers. Gojek can provide transportation services at low prices that are needed by the community both employees, the general public and students / students (Yuliantari, 2017)

Weaknesses-Opportunities Strategy, namely: (1) Control of Gojek drivers. PT Gojek Indonesia gives the driver a chance to make three mistakes. That is, if the Gojek driver gets three yellow cards, PT Gojek Indonesia will terminate the contract with the driver. Violations that are rewarded with a yellow card from PT Gojek Indonesia are usually concerned with protests and poor ratings from customers such as "Drivers who like speeding, do not use Gojek attributes, and 
are not friendly". Meanwhile, a red card is given to drivers who commit criminal acts and submit their solutions to the police, (2) The method of communication between PT Gojek Indonesia and the driver should be better. Gojek drivers as partners, but have never been involved in decision making. Gojek drivers do not have a formal organization that can help them talk to PT Gojek Indonesia's management. Building a representation body can help drivers mediate conflicts that can arise in the future, and (3) Improve existing applications. This application is not completely perfect, there are still many bugs that need to be fixed, thus overcoming problems arising from the lack of existing applications that can harm drivers and consumers (Yuliantari, 2017)

The Strengths-Threats Strategy, namely: (1) Developing the competitiveness of PT Gojek Indonesia can create the impression of the best service by providing more varied products that naturally follow the tastes of the market. With the slogan An Ojek for Every Need, PT Gojek Indonesia not only provides passenger transportation transportation services, but also provides courier services for shipping documents and goods, shopping services, and GoFood for food delivery messages. PT Gojek Indonesia launched the Go-World service that offers three new services, namely: Cleaning services for cleaning houses or offices; Massage services for call massage; and beauty services like a mobile salon. All types of services can be ordered by customers through the application. PT Gojek Indonesia hopes that the launch of this service can erode the unemployed who have expertise but find it difficult to find work, make it easier for customers who are left behind by their maid, make it easier for everyone to have relaxation and beauty services without having to go to a spa or salon, (2) Establish rates that reasonably priced for service users Pricing activities play an important role in the marketing mix process. Pricing decisions are very important in determining how far a service is valued by consumers and the image development process. Pricing also gives a certain perception in terms of quality. In this case, PT Gojek Indonesia sets a fairly cheap tariff for its service users so that consumers who used to use a motorcycle taxi then go to Gojek, (3) Provides many benefits for consumers. After popping up competitors who were almost similar to Gojek. Gojek did several ways to keep Gojek in existence among Indonesian people. Gojek adds services that can provide many benefits for consumers as seen from the various service features offered by Gojek such as Go-Send, GoRide, Go-Food, Go-Mart, Go-Box, GoClean, Go-Glam, Go -Message, and GoCourier. So, now Gojek does not only serve the community shuttle but Gojek also helps consumers in delivering and picking up goods, buying cinema tickets, food delivery so that consumers do not need to leave the house and queue free. This is certainly an advantage for PT Gojek Indonesia compared to other companies so that it can be said that this is very spoiled for consumers. In fact, PT Gojek Indonesia plans to work with the government so that Gojek can join or collaborate with TransJakarta. The new service that will be issued is Go-Busway. This was done in order to help busway riders and passengers. In terms of scheduling and checking the readiness of the fleet then looking for a motorcycle to be more timely to the office, and (4) Adding a strategy in the promotion of services. To further introduce Gojek services, advertising media are needed using internet, social media, brochures, radio, direct selling, events, media partners, and also through traditional marketing such as word of mouth publications. Gojek itself is already very familiar among artists so that in this case Gojek utilizes artists as brand ambassadors to attract consumers (Yuliantari, 2017).

Based on the results of research on the strategy of PT Gojek Indonesia in 
accordance with the theory according to Assauri (2013) regarding the Elements of Marketing Strategy that one element in the marketing strategy is the marketing mix which is a strategy run by the company which is related to determining how the company presents its product offerings in certain market segments, which are its target market. There are four elements of the marketing mix which are marketing strategies. The elements used as a marketing mix according to Assauri, (2013) are as follows:

Product Strategy. The product strategy in this case is to establish ways and to provide the right products for the target market, so that it can satisfy its customers and at the same time increase company profits in the long run, through increasing sales and increasing market share. The product strategy that can be carried out includes decisions on product mix, brand, product packaging, product quality, and services provided.

Pricing Strategy. Price is the only element of the marketing mix that generates sales revenue, while the other elements are just ordinary elements. The role of prices is very important especially to maintain and improve the company's position in the market, which is reflected in the company's market share, in addition to increasing sales and company profits. In other words, pricing affects the company's competitive ability and the company's ability to influence consumers.

Distribution Strategy (Distribution). Distribution is the activity of delivering the product to the hands of the user or the consumer at the right time. Distribution policy is one of the integrated marketing policies that includes the determination of marketing channels (marketing channels) and physical distribution.

Promotion Strategy. Companies must try to influence consumers, to create demand for the product, then maintained and developed through promotional activities which are one of the references / marketing mix. Promotions must be in line with the overall marketing plan, and planned to be well directed and controlled. According to Tjiptono (2002) promotion is a form of marketing communication meaning marketing activities that seek to disseminate information, influence / persuade and or remind target markets for companies and their products to be willing to accept, buy, and be loyal to the products offered by the companies concerned. According to Sistaningrum (2002) promotion is an effort or activity of a company in influencing actual and potential consumers so that they are willing to make a purchase of products offered now or in the future. According to Kotler (2000) promotion is a part and process of marketing strategy as a way to communicate with the market using the promotional mix composition. According to Lupiyoadi \& Hamdani (2006) promotion is one of the variables in the marketing mix that is very important to be implemented by companies in marketing service products.

\section{Implementation of the Strategy and its Implications}

Implementation of the strategies and implications of the Object are as follows: Penetration strategies by:

Continue to innovate for improvement. Internal IT systems by utilizing the many new applications available with the development of a contemporary nature, where consumers of Gojek service users will not only be able to know the point of existence of Gojek / Go-How to pick up, travel routes, estimated pickup times, tracking call drivers, including costs travel, but with this innovation, consumers will be able to order a motorcycle for a certain time in the future (not now) for example to go to customer tomorrow, receive proof of payment by electronic mail. This needs to be done in addition to counter opposition from its competitors, as well as to maintain the high interest of people who know them as providers of transportation services that are transparent, safe, cheap, effective. So 
that the position of Gojek as a leader in the field of online-based transportation services can be maintained, (2) To achieve this, Gojek needs to improve the quality, loyalty, and performance of all employee components by sending them to study, training, and bring in consultants in the field of Tech Business, so as to create new service ideas, this strategy needs to be done in addition to spurring the creativity and productivity of all employee components as well as to anticipate intense competition in the transportation business. As you well know, Gojek is a pioneer in the field of online-based motorcycle taxi, if no serious anticipation is made, it will be vulnerable to the opposition of its competitors, especially the resistance made by Uber and Grab, (3) Form a special marketing team by educating drivers to develop relationships personal with the customer where the customer has the right to determine / choose the driver in accordance with the desired characteristics and criteria. This strategy needs to be done because Gojek has a wider network of drivers with good service quality management such as: usability, responsiveness, assurance, empathy, and tangibility. With this strategy, consumers will not only be able to easily get transportation services using only the cellphones they have, but they can also be served by drivers they are very familiar with, (4) Creating special applications that can be used to manage and improve services for partners A driver is an application that can detect driver buildup points and distribute them to wet spots (many requests) but few drivers. The application working system is almost the same as the application created by Gojek when facing the problem of the widespread use of fake GPS applications or "Tuyul" by rogue driver partners. Responding to this problem, Gojek immediately developed a new system that can detect the presence of fake GPS on mobile phones, as well as announcing the implementation of the "Delete Tuyul" policy to all driver partners. With regard to the frequent occurrence of driver partner buildup, Gojek can also create similar applications, only the function is more focused on detecting driver buildup points and distributing them to wet spots (many service requests) but lonely drivers. With the creation of this new system, the Gojek driver partners are more flexible in providing services, without having to wait in a queue, which is likely to be quite long. If this system is realized, drivers' income will increase and their loyalty and solidity towards Gojek will also increase, (5) Educating the public about the importance of technological benefits and promoting them if Gojek's services are not only a 2wheeled transportation mode but also a 4wheeled transportation, including other services such as GoRide, Go-Car, GoFood, Go-Send, Go-Mart, Go-Box, GoMassage, Go-Clean, Go-Glam, Go-Tix, Go-Busway, Go-Pay, Go-Med , Go-Auto and the latest is Go-Pulsa. This promotion needs to be continuously carried out by Gojek, especially promotions aimed at people who are not yet tech-savvy. They need to be made aware if Gojek makes it easy for them to provide transportation facilities. The principle works simply, how consumers can easily get transportation just by using the cellphone they have. This application works by determining coordinates using the Global Positioning System (GPS) to detect the presence of consumers and determine pickup locations and intercompany locations. With this system, driver partners can easily approach consumers precisely and precisely because their location has been determined based on GPS.

Market and product development strategies by: (1) Expanding the use of GoPay to control more retail both online and offline. By optimizing the benefits of GoPay which will be operated like an e-wallet in general, such as Sakuku or Doku. Which becomes a means of payment in a number of e-commerce and offline for merchants who have joined the Gojek service. 
Through Go-Pay, customers don't need to worry anymore when paying for various Gojek services. Because with Go-Pay, customers and partners will not be bothered in finding change. With Go-Pay, transactions of non-cash financial services are easier, more convenient and secure. Moreover, customers who do not have a bank account can still use Go-Pay. This is because one way to top-up Go-Pay is through a driver partner. Besides with GoPay, now customers can also make cash withdrawals and balance transfers between Go-Pay users. What needs to be taken into account Gojek is how the money planted by custumer in an electronic wallet really gives added value. Because, so far most ewallet players do not offer interest or yields for the remaining balance. Thus, many consumers think that if their e-wallet is not used, the value of the money that they have deposited in the e-wallet will continue to decline due to inflation. Another thing that needs to be taken into account by Go-Pay is a matter of e-wallet transfers. So far, customers can only transfer funds to other e-wallet users. So it does not provide flexibility for consumers to transfer each other to a different ewallet. Likewise with a limited e-wallet balance, which is a maximum of IDR 10 million. For this reason, if Go-Pay wants to fight in the e-wallet market, the various considerations above must be properly executed, so that Go-Pay can provide differentiation for digital businesses, (2) Extending the distribution reach to peripheral areas by means of expanding cooperation and collaboration with Regency / City Governments in improving public services, especially in transportation services and socializing with pangkalan taxi drivers (Opang) with the aim of providing an explanation if Gojek is present not as a threat to them (Opang), but Gojek is present wanting to invite cooperation and make Opang a partner for Gojek, because if the base motorcycle taxi drivers are willing to join, then the benefits they get will be far greater than their current income as Opang. With frequent invitations like this, the marginal communities that have not been touched by Gojek services can be well served, (3) Creating a Cause Related Marketing program, a program that combines Gojek marketing and its concern for social reality in the community. This program can be done by Gojek by involving non-profit organizations that care about social reality. The form of the program can be in the form of every Rp 10,000, - paid by consumers when enjoying Gojek services, then $\mathrm{Rp} 1,000$, - will be donated to nonprofit organizations for activities (eg improving the quality of clean water, improving community nutrition, preventing cancer, etc.). With this program customers who use the Gojek service will automatically also contribute to the Cause Related Marketing program. There are several benefits obtained by Gojek by implementing this program, namely: Can improve the company's reputation; Can attract press attention to cover; Can introduce them or products to be more widely known; Can increase customer loyalty; and can increase sales (Theaker, 2001).

Integration strategy, which is done by: (1) Forward integration strategy by forming a special marketing team by involving drivers to serve corporate customers who want to join their services. This strategy needs to be done because many large corporations that for the sake of transportation of their employees, rent cars in large numbers. If this condition is done seriously by Gojek's marketing team by providing its own interface and features that make it easy for corporate customers to optimize the use of Gojek's services, especially Go-Car and Go-Send, it will certainly bring great reliability and benefits for Gojek, (2) Strategy horizontal integration by collaborating with all parties considered as Gojek's strict competitors, such as the partnership that Gojek currently has with Blue Bird. The form of partnership is in the form of application 
integration that allows Gojek users to order the Blue Bird taxi fleet through the Go-Car service. There are 2 forms, namely in the Gojek app, the Go-Blue Bird subapplication is provided, which facilitates whoever the consumer wants to order a Taxi with a Blue Bird tariff (not a Gojek tariff) and makes the Taxi Blue Bird a part of the Go-Car service, where consumers those who ordered a Gojek could be the car that picked him up not a private car, but a Blue Bird Taxi, but at a Go-Car rate (not a Blue Bird fare) (Sudarmadi, 2018). In addition to partnering with Blue Bird, the horizontal integration strategy undertaken by Gojek is by acquiring Kartuku, Midtrans and Mapan. This is done by Gojek as a strategic step in strengthening the Go-Pay foundation in the Indonesian Fintech industry. This acquisition will be a leap in Gojek from a company that initially only became a transportation service provider, becoming a company that also mastered multi-platform technology that focuses on digital payments (Arifin, 2019).

\section{Gojek's Marketing Strategy}

Farida et. al. research (2016) states that Gojek is the top of mind for online motorcycle taxi consumers in Indonesia, Gojek has a higher market share compared to Grab because Gojek's marketing strategy that forms a service brand is strong. This finding is supported by Vidyastuti's research (2016) which also found that Gojek's marketing strategy made consumers replace the word online motorcycle taxi with the brand name "Gojek" (Rizal, 2018)

Various attempts were made by Gojek to market its products including marketing public relations strategies such as Go-Pay discounts, Gojek memes, nationalism campaigns, and Indonesian league endorse. Utari \& Sharif's findings (2016) explain that marketing strategies through Go-Point increase repurchases of Gojek consumers (Rizal, 2018)

According to Gde \& Dalem (2017) the marketing strategies adopted at PT
Gojek Indonesia are: First, Advertising is related to marketing strategies carried out by marketing in increasing consumer brand awareness of the services owned by PT Gojek Indonesia through the use of advertising media such as brochures, $\mathrm{x}$ banners, roll banners, banners and merchandise. Second, Sales promotion in the marketing sales promotion strategy has several sales promotion strategies in increasing the brand awareness of PT Gojek Indonesia such as the Promotion Code given to new consumers / new downloaders of the Gojek application. With this promotional code, consumers can use it as a balance that can later be used to pay for the Gojek services for free and marketing Gojek provides free transportation (free shutle), free transportation is usually given when attending events that sometimes the event location is far from the venue. This is done to attract consumers to get used to using the services of Gojek. Third, Direct marketing, in conducting direct marketing programs, Gojek marketing uses social media as one of the marketing tools that plays an important role in branding a Gojek company and its services. By using social media the marketing can post promotions offered by the company or activities carried out by ojek employees. The social media owned by PT Gojek Indonesia are Youtube, Instagram, Facebook Fanpage, Twitter, Website, and Google AdWords. Fourth, Publication / Public Relations, marketing programs carried out by Gojek marketing in communicating the company's brand to the public is to take advantage of offline events held such as attending Jazz Festivals and others. The things done at the event such as opening a Gojek boat / stand, distributing promotional material (brochures / flyers), inviting event visitors to download the application and educating visitors about how to use the application. In addition to organizing events, the marketing of Gojek also cooperates with several hotels by providing special 
discounts for Gojek users who stay at the hotel.

\section{Gojek Business Strategy Management Overview of Gojek}

When it was first formed, Gojek was a service call center to help prospective customers find motorcycle taxi drivers. Through text messages and telephone calls manually, the company also cooperates with the motorcycle taxi base. But this apparently did not make it experience development. So when Grab and Uber entered Indonesia in 2014, then the company made by Nadiem Makarim improved the system to attract investors. As a startup made by the children of the nation, Gojek received extraordinary appreciation from the people of Indonesia. They also received funds from one of the giants from China, Tencent, amounting to 16.8 billion rupiah. Until now, many awards were obtained, such as the winner of the Fintech Award by Bank Indonesia, and the Asian of the Year Award from The Strait Times (Grapadi, 2019),

\section{Driver Recruitment}

Successful is widely known, in January 2015 Gojek recruited 10,000 drivers and still has a target the following year. In addition, there are also some people who deliberately applied to become drivers. Increasing the number of drivers is the target of Gojek to expand the market to remote areas. Running simultaneously, the company also improves service quality by paying attention to safety. To make this happen, it was decided to work with Rifat Drive Labs (RDL). There the drivers get safety training. RDL has also prepared insurance for its drivers and passengers (Grapadi, 2019).

\section{Promos for Consumers Promotional}

Programs are an effective way to attract potential customers. This is a way to introduce broader services. Consumers are more profitable because only by paying 10,000 can be delivered to any destination, but the distance limit is determined. There are also promo discounts up to 20 thousand rupiah to order food in any restaurant. Plus a discount voucher at a particular cafe or restaurant, so customers can get cheaper prices than usual. Promo is one part ofstrategy marketing (Grapadi, 2019).

\section{Management Model Another}

Thing that is no less important in a startup culture is adapting solid products and services to demand. So in its business practices, Gojek establishes three strategies, namely innovative, dynamic, and maximizing opportunities in the digital age. Nadiem Makarim, as the founder, has a different angle on how to develop a business. He believes that each team leader has their own way of managing, as long as they reach their targets. So the approach leadership-based Freedom and Responsibility can generate new ideas. The combination of capacity and mobilization resource from stakeholders and a collaborative and exclusive organizational style makes the Gojek ecosystem more dynamic and ready to face intense competition (Grapadi, 2019).

\section{Features and Cooperation}

Successful with transportation online, Gojek then added new features amid intense competition. Not just offering ridesharing app services, several other facilities that are interesting and easy for the public such as Go-Car, Go-Food, GoMart, Go-Box, Go-Glam, Go-Clean, GoMassage, Go-Tix, and Go-Med. With these features, in 2016 Gojek experienced an increase in the number of drivers, namely 250,000 two and four wheels, 3000 service providers, and 35,000 Go-Food merchants. Managing business with this system, they create a culture of reciprocity that is mutually beneficial. Blue bird, one of Gojek's strong competitors, finally joined and became a partner. Logistics companies also participated join, so that they could improve service. This method is a win-win solution that creates healthy ecosystems 
(Grapadi, 2019).

\section{Pricing Strategy}

One of the strategies marketing implemented by Gojek is to determine tariffs. This aspect is just as important as thinking about further expansion because from there consumers can judge whether these services are good or not. Pricing rates can also be a benchmark or build an image. Concerning the price, the company has a stapenggunard that is cheap enough to make regular motorcycle taxi users go online (Grapadi, 2019).

\section{Marketing Strategy: "GoGo Your Version" Promo}

One of the promos introduced by PT Gojek Indonesia is "Gojek Your Version". To be able to benefit from this promo, application users must firstupdate the Gojek application. Then, on the home page of the application, click the "Other" button in the lower right second row of the front page and press edit. As a variation, this promo was introduced in the form of three versions, namely the Gozali version, the version, Announcer Cinema, and the Kunti version (Soelistyowati, 2018).

The current communication situation is in line with the theory of innovation diffusion introduced by Lazarsfeld, Berelson, \& Gaudet (1944) who say that the communicant who gets the message from the mass media is very strong to influence people. Thus, innovation (discovery) that is spread (diffusion) through the mass media will strongly influence the mass that follows it (Nurudin, 2007). If the explanation of this theory is translated into daily life (Soelistyowati, 2018).

At present, the internet is very aggressively advertising Gojek, specifically advertising the "Gojek Your Version" promo through the social network Youtube, where users of the Gojek application can adjust the service menu available on the application based on the level of intensity of user needs in each service and are also able to provide recommendations according to the needs of users on each type of service in the application. Of course this new promo raises people's curiosity. People then came to know that Gojek is a transportation tool that can be ordered online. Then people want to try it, so that now Gojek has been widely used. So, there is an innovation "Gojek Your Version" spread by Youtube as a new mass media (diffusion) and then used by the community (adopter) (Soelistyowati, 2018).

\section{Jo \& Jek Introducing Ad Strategy on Youtube}

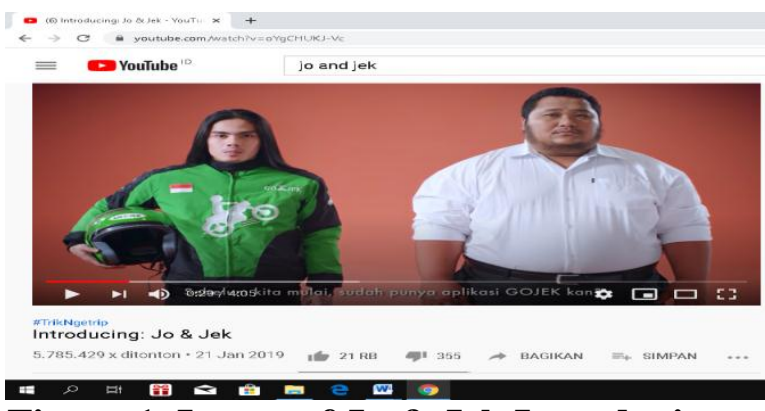

Figure 1. Image of Jo \& Jek Introducing Ad

Source: Youtube Gojek Indonesia (2020)

Gojek is one of the technology companies that uses advertising as its promotional media. The advertisements themselves are no exception Introducing Jo \& Jek is the result of hard work from his creative team, namely Gojek Creative Labs. Advertising Introducing Jo \& Jek'sitself takes the topic of a driving guide demonstrated by Jo (customer) and Jek (partner). The first time it aired on January 20, 2019 on Youtube, the ad was present on the basis of an open letter from partners to the Founder \& CEO of GOJEK Group, Nadiem Makarim to make a socialization of the use of helmets to customers

The letter received a response from Gojek by presenting advertisements with characters Jo and Jek to invite the audience to drive with discipline in accordance with applicable rules while promoting safe and 
comfortable Gojek services (Swastika, 2019)

Creativity in the packaging of advertisements Introducing Jo \& Jek'sthat are light and The humorist stole the hearts of netizens. This also caused within a relatively short period of time, his advertisement which lasted for four minutes and six seconds was successfully watched more than 5.5 million times, liked by 18 thousand viewers, and received approximately 1.5 thousand comments as of May 6, 2019 ( Swastika, 2019)

The concept ofadvertisement Introducing Jo \& Jek'sis a driving guide, so it is not surprising that there are some traffic rules to support the safety and safety of motorists (Swastika, 2019).

The first scene shows the audience, including partners not to transport its passengers incorrectly because it is dangerous. The next scene is the provision of helmets made by Jek (partners) to Jo (customer). This scene indirectly gives an impression that Gojek cares about the safety of the customer (customer). This is evident from the moderator's sentence that reads, "If you have met the passenger, give him a helmet and fasten the belt". This is to show and emphasize that the use of helmets is basic but essential in driving, not only to protect the head but also hearing aids (Swastika, 2019).

The next scene also indicates Gojek's concern through partners who want customers to be able to drive safely and comfortable by tightening the seat belt on the helmet. This is to anticipate the unexpected things in driving on the highway. One of the rules contained inadvertisement is Introducing Jo \& Jek'srelated to driving speed. Although using other safety such as helmets, speed problems also greatly affect the safety, comfort, and safety of motorists and passengers. In the advertisement, described a racer who drives using a helmet with a speed of $15 \mathrm{~km} /$ hour. It aims to give an example to the audience to be able to drive according to the rules in force in Indonesia (Swastika, 2019).

The purpose of making advertising must be able to inform, persuade and remind buyers about the products offered by the company through the advertising media. To be useful for companies in carrying out marketing functions, advertising must be flexible, stable, sustainable, and simple, and easy to understand. This requires analysis, forecasting, and development of the advertising business by considering everything making advertising as a continuous process.

Advertising activities must be evaluated to find out whether they are clear, easy to understand, and accurate and right on target. Advertising also needs to pay attention to the principles of comprehensiveness, unity, and consistency. Cost effectiveness concerns the time, effort and emotional flow of achieving the advertisement. Then advertising must also consider aspects of the responsibility for the implementation of these advertisements and responsibility for the implementation of advertising activities. So that all advertising activities that have been carried out will be on time as planned. If the purpose of advertising can be achieved, by first selecting the appropriate media and making a budget for advertising activities, then an advertisement can be said to be effective. The effectiveness of advertising can be measured using the EPIC Model. The EPIC model consists of four dimensions as follows: (1) The empathy dimension, (2) The persuasion dimension, (3) The empty dimension, and (4) The communication dimension (Swastika, 2019).

\section{Netizen Opinions on Gojek Promotion Advertising Strategy on Youtube}

Youtube Go Indonesia already has

128 thousand subscribers. Gojek's advertising video titled "Introducing Jo \& Jek" until June 11, 2020 has been watched 5.7 million times since it was launched in 
2019. Get as many as 21 thousand likes and as many as 1,499 comments, almost all of which have positive comments on the ad video as some of the following comments: According to Rahmatbs account: "The best ads I've ever seen". According to the Cyber Crime account: "This is what I called advertisements, no alay, no lebay, good". According to Saychan Chan's account: "I think I've watched more than 5 times this ad until after. LOL Good job Gojek". According to the Heykal Audah account: "Classy + ga monotonous ads. It's not like "Users really have to know to pay using Sopo for only 1 rupiah. Terms and Conditions apply. LOL". According to an account Black: "Ad youtube Gojek skip my first ga and I watch" reset. "According to the Gilang Fidriansyach account: "Who is the video producer who is cool when the message gets, is entertaining, and is fresh". According to our Galaxy account: "Crazy ... This ad is awesome. Not Alay". According to the Astreaprime account: "How did you make a good commercial? Go-Jek: Yes". According to the Reygha account: "Happy Gojek. This is the first Youtube ad that I watched after without skip, whatever the ad 5 seconds definitely skip, but not this one". According to Zulfa Asfihani's account:" The only ad I wait for and I never skip? Champion!". According to Jan Nugroho's account: "What are you watching watching ads, usually discs". According to Pras_Tya account: "Now this is just the quality advertisements that I'm looking for in Indonesia, hopefully other ads are also funny like this". According to Dody Hulk Prawato's account: "Wedus, gojek are always smart for the concept of entertaining advertisements like this, insane creative team of adverts". According to the Radar Emien account: "Fun and entertaining video, steady soul". According to Chandra Danuarta account: "Quality ads". According to the Fajar account Imani Firdaus: "The ad is entertaining. Mantaps Gojek ". According to the account of Mehdy Noermohammed:" One of the adver- tisements that not only did not I skip, but I traced until the channel. Goodjob Gojek". According to the Deavy Try Ayu account:" Ads that are genius \& severe educative, the message is very good to consumers, salute the creative team of Gojek". According to Yoga Ramadhan account:" This is a classy advertisement". According to the Electra Pandoro account: "I love this. This good content over here". Thus, based on the results of the above research it can be seen that Gojek's marketing strategy utilizes the internet as a means to promote the services offered. The promotion process is very intensively carried out by the Gojek Company, one of them through social media, especially YouTube. With the sophistication of advertising done through social media, users will automatically be treated to various promotions from the Gojek Company when opening its social media pages. This strategy is very appropriate because almost the entire process of purchasing a Gojek service is done in a smartphone application, this means that the potential customers targeted are in accordance with the audience of advertisements installed.

\section{CONCLUSIONS AND RECOMMEN- DATIONS Conclusions}

Conclusions from this research that the implementation of marketing $7 \mathrm{P}$ on Gojek online services can be broadly described as follows: (1) Product. Gojek online provides a package of shuttle services both in the form of goods and people, where similar services in other businesses are still fragmented, such as only to deliver goods, but not for human transportation, or vice versa, (2) Price. The price system offered is relatively cheaper, more open, and has the same standard based on the distance traveled, so that customers can predict the possible costs they will incur, (3) Place. Online online taxi services are everywhere so they are easy to obtain, (4) Promotion. Gojek online uses promotional tools in the form of 
applications that can be downloaded on the commonly used personal communication tools (smartphones) and they also promote their services through other media tools, (5) People. Gojek services have their own management, and the personnel involved are provided with basic training and a separate recruitment system, (6) Process. To obtain Gojek services, customers can use the available online Gojek application, and specify the desired location (destination and pick-up place) so that it will facilitate the online Gojek service process, and (7) Physical Evidence. The physical form of Gojek is green-and-white transportation and a helmet that reads "Gojek"

Youtube Gojek Indonesia already has 128 thousand subscribers. One of the promos introduced by PT Gojek Indonesia is "Gojek Your Version". where the Gojek application user can set the service menu in the application based on the level of intensity of user needs in each service. Besides that, creativity in the packaging ofadvertisements Introducing humorous and humorousJo \& Jekhas stolen the hearts of netizens, which until June 11, 2020 has been watched 5.7 million times since it was launched in 2019. Get as many as 21 thousand likes and as many as 1,499 comments, almost all of which have positive comments on the video ad.

\section{Recommendations}

Recommendations in this study are expected to Gojek to continue to innovate in making video advertisements on YouTube as an effective promotional media.

\section{Limitations}

Limitations in this study about analysis of Gojek's marketing strategy through social media which is carried out using the research method, namely netnography. It is hoped that in the future this research can be used as material for thought as a basis for researchers to examine the same management elements, namely marketing using social media or other different research objects.

\section{REFERENCES}

Anindhita, W., Arisanty, M., \& Rahmawati, D. (2016). Analisis Penerapan Teknologi Komunikasi Tepat Guna Pada Bisnis Transportasi Ojek Online (Studi pada Bisnis Gojek dan Grab Bike dalam Penggunaan Teknologi Komunikasi Tepat Guna untuk Mengembangkan Bisnis Transportasi). In Prosiding Seminar Nasional INDOCOMPAC, 1-3.

Arifin, Z. (2018). Strategi Bersaing Gojek di Tengah Ketetnya Persaingan Moda Transportasi. Arthavidya, 20(2), 1-29

Assauri, S. (2013). Manajemen Pemasaran. Jakarta: Rajawali Pers.

Carr, C. T., \& Hayes, R. A. (2015). Social Media : Defining, Developing, and Divining. Atlantic journal of communication, 23(1), 46-65.

Clearesta, I., Angelina, G., \& Wiradharma, G. (2015). Pengalaman Konsumen Terhadap Layanan Gojek di Kota Jakarta: Studi Kualitatif Deskriptif. Jurnal Komunikasi dan Bisnis, VI(1), 70-80.

Denney, A. S., \& Tewksburry, R. (2013). How to Write a Literature Review. Journal of criminal justice education, 24(2), 218-234.

Farida, I., Tarmizi, A., \& November, Y. (2016). Analisis Pengaruh Bauran Pemasaran 7P terhadap Kepuasan Pelanggan Pengguna Gojek Online. Jurnal Riset Manajemen dan Bisnis (JRMB) Fakultas Ekonomi UNIAT, 1(1), 31-40.

Firmansyah, D. W. (2018). Analisis Strategi Komunikasi Pemasaran Media Sosial melalui Brand Ambassador pada Cakekinian. Jurnal Ilmiah Mahasiswa FEB , 7(2), 2-5.

Gde, A. A., \& Dalem, A. P. (2017). Analisis Strategi Komunikasi Pemasaran Jasa Gojek dalam Meningkatkan Brand Awareness Cabang Bali. Jurnal Kajian Ilmu Komunikasi, 15(2), . 
Gojek. (2019). Dipetik Juni 2, 2020, dari Gojek Indonesia: https://www.gojek.com/about/

Grapadi. (2019). Dipetik Juni 1, 2020, dari Perbedaan Manajemen Bisnis Gojek dan Grab: https://grapadinews.co.id/ perbedaan-manajemen-bisnis-gojekdan-grab-1/

Hermawan. (2019). NESABAMEDIA. Dipetik Juni 5, 2020, dari Pengertian Youtube Beserta Manfaat dan Fitur-fitur Youtube yang Perlu Anda Ketahui: https://www.nesabamedia.com/pengerti an-youtube/

Hermawan, S., \& Amirullah. (2016). Metode Penelitian Bisnis Pendekatan Kuantitatif Dan Kualitatif. Malang: Media Nusa Creative.

Kotler, P. (2000). Prinsip-Prinsip Manajemen. Jakarta: Prenhalindo.

Kotler, P., \& Amstrong, G. (2008). Prinsip-Prinsip Pemasaran. Jakarta: Erlangga.

Kotler, P., \& Amstrong, G. (2012). Principles of Marketing. New Jersey: Prentice Hall.

Kotler, \& Keller. (2012). Manajemen Pemasaran. Jakarta: Erlangga.

Kozinets, R. V. (2010). Networked Narratives: Understanding Word-of Mouth Marketing in Online Communities. Journal of marketing, 74(2), 71-89.

Lazarsfeld, P., Berelson, B., \& Hazel, G. (1994). The People's Choice. New York: Columbia University Press.

Lupiyoadi \& Hamdani. (2006). Manajemen Pemasaran Jasa. Jakarta: Salemba Empat.

Markey. (2018). Dipetik Juni 1, 2020, dari Sejarah Gojek Indonesia, Profil, Fitur \& Layanannya: https://markey.id/blog/bisnis/gojekindonesia

Nurudin. (2007). Pengantar Komunikasi Massa. Jakarta: Raja Grafindo Persada.
Ramadhayanti, A. (2019). Strategi Pemasaran di YouTube Melalui Subscriber \& Komentar dan Perspektif Persuader Terhadap Keputusan Pembelian . Jurnal Manajemen Inovasi, 10(1), 9-21.

Rizal, M. (2018). analisis Strategi Pemasaran Gojek Indonesia Pasca Keluarnya Uber dari Pasar Transportasi Daring Indonesia . Jurnal Ekobis: Ekonomi Bisnis \& Manajemen, 8(2), 91-101.

Sanjaya, R., \& Tarigan, J. (2009). Creative Digital Marketing. Jakarta: PT Elex Media Komputindo.

Soelistyowati, R. D. (2018). Peran Youtube dalam Membangun Brand Image Bagi Pengguna Aplikasi Gojek. In DiMCC Conference Proceeding, 1, 165-176.

Stanton, W. (2001). Prinsip-Prinsip Pemasaran. Jakarta: Erlangga.

Sudaryono. (2016). Manajemen Pemasaran: Teori dan Implementasi. Yogyakarta: ANDI.

Sugiyono. (2011). Metode Penelitian Kuantitatif, Kualitatif, dan $R \& D$. Bandung: Alfabeta.

Swastika, V. (2019). Analisis Efektivitas Iklan Video Online Gojek Versi Introducing: Jo \& Jek Menggunakan Direct Rating Method. Skripsi. Bandar Lampung: Universitas Lampung.

Tambajong, G. (2013). Bauran Pemasaran Pengaruhnya Terhadap Penjualan Sepeda Motor Yamaha di PT Niaga Megah Kerta Manado. Jurnal Riset Ekonomi, Manajemen, Bisnis dan Akuntansi, 1(3), 1291-1301.

Theaker, A. (2001). The Public Relations Handbook. London: Roultledge.

Tjiptono, F. (2002). Manajemen Jasa. Yogyakarta: ANDI.

Tjiptono, F. (2014). Pemasaran Jasa Prinsip, Penerapan, dan Penelitian. Yogyakarta: Andi Offset.

Turban, E. (2004). Electronic Commerce a Managerial Perspective. New Jersey: Pearson Education International. 
Utari, N. L., \& Sharif, O. O. (2016). Analysis of Service Quality of Go-Jek Indonesia in Jabodetabek, Bandung, Surabaya, Bali and Makassar . Journal of Business and Management, 18(4), 93-98.

Vidyastuti, H. A. (2016). Kinerja Bauran Pemasaran Jasa Transportasi Roda Dua Dalam Meningkatkan Keunggulan Bersaing Serta Pengaruhnya Pada Loyalitas Pelanggan. Jurnal Ekonomi dan Manajemen STIE Dharma Negara, I(1), 18-24.

Yuliantari, K. (2017). SWOT dalam Menentikan Strategi. Widya Cipta: Jurnal Sekretari dan Manajemen, 1(1), 92-99. 